\title{
PENYUSUNAN DESIGN KURIKULUM BERBASIS KKNI PADA PROGRAM STUDI TADRIS BAHASA INGGRIS PTKIN (STUDI KASUS PADA IAIN BENGKULU DAN STAIN CURUP)
}

\author{
Rizkan A. Rahman \\ IAIN Bengkulu \\ rizkan@gmail.com
}

\begin{abstract}
This study aims to determine the prospects and readiness of two College of Religious Islam Negeri (PTKIN) under the Ministry of Religious Affairs (IAIN Bengkulu and STAIN Curup) which undertake study Program of Tadris English toward discourse of imposition curriculum based KKNI effectively will be enacted in the academic year 2016 / 2017 as which as has been launched nationally through legislation President number 8 in 2012 and later translated into rule of education minester by number 73 in 2013. through the study program or department Tadris English being object of the achievements of learning (learning outcomes) plays as LPTK (educational institution for generating teacher), namely container nursery candidates qualified English teacher, is worth competitiveness and dedicated. Besides, this research aims to become a means of discovery of solutions to problems that become obstacles from the imposition of KKNI based curriculum. Indonesian National Qualifications Framework (KKNI) is a national reference for improving the quality and competitiveness of Indonesia in the sector of human resources through the achievement of qualifications of human resources Indonesia produced by the educational system and national job training system, as well as learning outcomes assessment system of equality. Improving the quality and competitiveness of the nation will simultaneously strengthen the identity of Indonesia. The results of this study illustrates that both PTKIN which organizes education courses in English in principle ready to perberlakuan KKNI based curriculum in the academic year 2016/2017, but the effectiveness of this policy seyogya coupled with the readiness of all the devices needed especially the structure of matter refers to an element of competence topical; (A) Basis of personality; (B) The mastery of knowledge and skills; (C) Ability to work; (D) Attitudes and behaviors in the work; and (e) Understanding the rules of Bohemian society. PTKIN Of the two, only the TBI study program IAIN Bengkulu who had started implementing the curriculum KKNI and running well while STAIN Curup still in the process of finalizing the structure of the curriculum and the ripening preparation necessary tools.
\end{abstract}

Keywords: KKNI, Curriculum Development, and PTKIN (state Islamic religious colleges) 
Abstrak. Penelitian ini bertujuan untuk mengetahui prospek dan kesiapan dua Sekolah Tinggi Agama Islam Negeri (PTKIN) di bawah Kementerian Agama (IAIN Bengkulu dan STAIN Curup) yang melaksanakan Program Studi Tadris English terhadap wacana penerapan kurikulum berbasis KKNI yang efektif akan diberlakukan. pada tahun akademik 2016/2016 seperti yang telah diluncurkan secara nasional melalui undangundang Presiden nomor 8 pada 2012 dan kemudian diterjemahkan ke dalam peraturan menteri pendidikan dengan nomor 73 pada tahun 2013. melalui program studi atau departemen Tadris Bahasa Inggris menjadi objek pencapaian pembelajaran (hasil pembelajaran) berperan sebagai LPTK (lembaga pendidikan untuk menghasilkan guru), yaitu calon pembibitan kontainer guru bahasa Inggris yang berkualitas, bernilai daya saing dan berdedikasi. Selain itu, penelitian ini bertujuan untuk menjadi sarana penemuan solusi untuk masalah yang menjadi hambatan dari pengenaan kurikulum berbasis KKNI. Kerangka Kualifikasi Nasional Indonesia (KKNI) adalah referensi nasional untuk meningkatkan kualitas dan daya saing Indonesia di sektor sumber daya manusia melalui pencapaian kualifikasi sumber daya manusia Indonesia yang dihasilkan oleh sistem pendidikan dan sistem pelatihan kerja nasional, serta hasil pembelajaran sistem penilaian kesetaraan. Meningkatkan kualitas dan daya saing bangsa secara bersamaan akan memperkuat identitas Indonesia. Hasil penelitian ini menggambarkan bahwa kedua PTKIN yang menyelenggarakan kursus pendidikan dalam bahasa Inggris pada prinsipnya siap untuk perberlakuan kurikulum berbasis KKNI pada tahun akademik 2016/2017, tetapi efektivitas kebijakan ini seyogya ditambah dengan kesiapan semua perangkat yang dibutuhkan terutama struktur materi mengacu pada elemen kompetensi topikal; (A) Dasar kepribadian; (B) Penguasaan pengetahuan dan keterampilan; (C) Kemampuan untuk bekerja; (D) Sikap dan perilaku dalam pekerjaan; dan (e) Memahami aturan masyarakat Bohemia. Dari dua PTKIN, hanya program studi TBI IAIN Bengkulu yang sudah mulai menerapkan kurikulum KKNI dan berjalan dengan baik sementara STAIN Curup masih dalam proses finalisasi struktur kurikulum dan persiapan pematangan alat yang diperlukan.

Kata Kunci: KKNI, Pengembangan Kurikulum, dan PTKIN (Perguruan Tinggi Agama Islam Negara)

\section{Pendahuluan}

Salah satu kunci untuk menentukan kualitas lulusan adalah kurikulum yang berkualitas sebagaimana disinyalir oleh Pratt, a curriculum contains many other kinds of intentions, such as what learnings students are to develop, the means of evaluation to be used to assess learning, the criteria according to which students will be admitted to the program, the materials and equipment to used, and the qualities required of teachers . Artinya, eksistensi kurikulum begitu penting dalam sistem pendidikan mencakup struktur personalia dan prosedur kerja bagaimana cara melakukan pembelajaran dan menjadi sarana evaluasi proses suatu pembelajaran. 
Melalui implementasi kurikulum berbasis KKNI ini diharapkan adanya perubahan perspektif positif dalam menilai dan mengukur kompotensi serta keterampilan lulusan, tidak lagi semata Ijazah tapi dengan melihat kepada kerangka kualifikasi yang disepakati secara nasional sebagai dasar pengakuan terhadap hasil pendidikan seseoran secara luas yang akuntabel dan transparan. Dengan kompotensi kurikulum ini, diharapkan tidak ada lagi para sarjana yang dihasilkan cuma siap latih bukan siap pakai. Sehingga dalam penyusunan bahanbahan ajar dalam kurikulum KKNI mata kuliah harus sesuai dengan kebutuhan publik termasuk kebutuhan dalam dirinya dalam menciptakan suatu lapangan kerja dengan tidak tergantung pada sector lapangan kerja formal. Dengan potensi pengetahuan, pengalaman dan keterampilan diharapkan lebih mandiri, profesional dan siap pakai untuk terjun ke masyarakat.

Program studi Pendidikan bahasa atau tadris bahasa Inggris (disingkat PBI/TBI), merupakan sebuah program studi di bawah naungan institusi perguruan tinggi setingkat Fakultas/Jurusan yang mewadahi kajian ilmu kependidikan dan tenaga kependidikan. Lembaga ini lebih akrab dengan istilah FKIP (Fakultas Keguruan dan Ilmu Pendidikan) terutama pada lembaga pendidikan tinggi umum, sementara itu pada pendidikan tinggi agama berada di bawah Fakultas Tarbiyah dan Tadris, dengan harapan dimana melalui optimalisasi lembaga ini dalam prosesi pembibitan dapat membidani caloncalon tenaga pendidik dalam bidang studi bahasa Inggris (tadris bahasa Inggris) yang mumpuni.

Tupoksi fakultas keguruan/tarbiyah yang menyelenggarakan program studi pendidikan sebagaimana halnya pendidikan bahasa inggris merupakan domain LPTK (lembaga Pendidikan Tenaga Kependidikan) yang memprioritaskan pengetahuan dan keterampilan pembelajaran-pengajaran di sekolah, tentu saja tidak terlepas dari acuan kurikulum yang memiliki kualifikasi sistem pembelajaran-pengajaran (teaching-learning system) yang dituntut adanya kemahiran secara tehnis dalam konteks didaktik-metodik dengan berbagai kaidah, aturan dan metode pembelajaran yang melekat di dalamnya. Kegiatan belajar-mengajar tadris bahasa Inggris dengan memiliki muatan kurikulum yang berorientasi pada empat aspek keahlian (skill) yang integrasi mesti dicapai, yaitu; Mendengarkan (Listening skill), Berbicara (Speaking skill), Membaca (Reading skill), dan Menulis (Writing skill). Tentu saja kemampuan bahasa ini harus dapat disampaikan dengan tuturan yang baik, efektif, dan efisien sebagai hasil dari communicating products. Kondisi faktual yang terkesan paradok di lapangan bahwa kedua perguruan tinggi sama-sama di bawah lingkup perguruan tinggi 
keagamaan Islam Negeri (PTKIN) dan berlokas di wilayah di Provinsi Bengkulu, yaitu IAIN Bengkulu dan STAIN Curup meskipun sama secara struktural tapi berbeda secara praktiknya. Kedua institusi yang menyelenggarakan program studi tadris bahasa Inggris ini belum menerapkan kurikulum berbasis KKNI sebagaimana yang diamanahkan oleh regulasi di atas dengan alasan belum tersedianya perangkat pembelajaran yang lengkap dan begitu juga SDM yang belum memenuhi kriteria sebagaimana yang diharapkan baik secara kualitas maupun kuantitas.

Padahal untuk menjembatani konsep dan pemahaman tentang prosedur serta sistematika penyusunan kurikukulum masing-masing prodi (prodi bahasa inggris) berbasis KKNI sebelumnya telah dilakukan sosialisasi melalui beberapa kegiatan ilmiah baik di lingkungan kampus (internal) maupun di luar kampus (eksternal) seperti; diklat, seminar, workshop dan lain-lain.

Selain itu permasalahan lain adalah ada diversi dalam perspekstif konten atau muatan inti kurikulum yang dinginkan terkesan dikotomi dan tumpang tindih dengan materi inti institusi yang dikemas dalam bingkai ilmu keislaman. kondisi ini menyebabkan pengelola program studi merasa kewalahan dalam menentukan kapasitas dan potensi matakuliah yang mesti ditawarkan kepada mahasiswa karena harus mempertimbangkan masing-masing perspektif, mulai dari level institusi, fakultas, jurusan dan program studi.

Permasalahan inti yang menyebabkan fenomena ini secara umum dapat diindifikasi, antara lain adalah; (a) belum adanya kesepahaman mekanisme penyusunan kurikulum prodi tadris bahasa Inggris berbasis KKNI; (b) persepsi tentang muatan inti kurikulum berbasis KKNI prodi tadris bahasa Inggris cendrung berbeda; (c) belum ada kesepakatan dalam penerapan kurikulum berbasis KKNI untuk prodi tadris bahasa Inggris.

Tujuan penelitian ini adalah untuk mencari jawaban atas pertanyaan-pertanyaan yang terkait dengan persoalan efektivitas pemberlakuan kurikulum berbasis KKNI pada program studi tadris bahasa Inggris di masing-masing lembaga pendidikan tenaga kependidikan.

Secara subtantif, signifikasi penelitian ini adalah dalam rangka menjembatani pemahaman mendasar, yaitu antara lain; Pertama, mensinerjikan persepsi dan konsep dikalangan pengelola prodi tadris bahasa inggris baik IAIN Bengkulu maupun STAIN Curup tentang subtansi materi inti dan proyeksi dalam pencapaian kompetensi yang dikehendaki dalam kurikulum prodi tadris berbasis KKNI. 
Kedua, mereduksi pola pikir pengelola prodi tadris bahasa inggris yang dikotomik sehingga perlu pemikiran dan kreativitas yang integratif dalam melakukan inovasi pengembangan kurikulum yang lebih fleksibel dan sesuai dengan kebutuhan pangsa pasar (publik);

Ketiga, Mengetahui sejauhmana arah serta kebutuhan sebagai implikasi dari efektivitas pengimplementasian Kurikulum Berbasis KKNI sehingga menjadi barometer pengembangan prodi tadris bahasa Inggris pada masing-masing institusi;

Keempat; menjadi bahan kajian dan tolak ukur dalam proses penyusunan draf kurikulum tadris bahasa inggris yang memiliki nilai plus dan bisa diterapkan secara optimal secara bersamaan baik pada kedua institusi ini maupun PTKIN lainnya;

Kelima, mematangkan penyusunan draft menjadi produk kurikulum prodi tadris bahasa Inggris berbasis KKNI pada PTKIN yang ada di Bengkulu sehingga dapat diterapkan secara permanen, efektif dan efisien.

Penelitian ini juga diharapkan bermanfaat baik secara teoritis maupun pragmatis bagi pengelola program studi bahasa inggris di PTKIN, begitu juga pemegang kebijakan pendidikan tinggi, dari jajaran pimpinan perguruan tinggi, ketua jurusan, ketua program studi hingga dosen sebagai ujung tombak penyelenggaran Prodi Tadris bahasa Inggris.

Melalui hasil penelitian ini nantinya diharapkan benar memberikan gambaran riil bagaimana mekanisme penyusunan draf kurikulum TBI berbasis KKNI sehingga nantinya dapat dijadikan rujukan bersama pembenahan sistem dan mekanisme penyelenggaraan pendidikan bahasa asing (Bahasa Inggris) yang baik guna mewujudkan proses membidani lahirnya tenaga pendidik di bidang bahasa inggris yang berkualitas, profesional dan intelektual.

Kerangka Kualifikasi Nasional Indonesia (KKNI) sendiri merupakan kerangka acuan minimal yang menjadi ukuran, pengakuan penjenjangan pendidikan yang dilakukan. KKNI juga disebut sebagai kerangka penjenjangan kualifikasi kompetensi yang dapat menyandingkan, menyetarakan, dan mengintegrasikan antara bidang pendidikan dan bidang pelatihan kerja serta pengalaman kerja dalam rangka pemberian pengakuan kompetensi kerja sesuai dengan struktur pekerjaan di berbagai sektor.

KKNI yang ditetapkan melalui Perpres Nomor 8 Tahun 2012 merupakan kerangka penjenjangan kualifikasi sumber daya manusia Indonesia yang 
menyandingkan, menyetarakan, dan mengintegrasikan sektor pendidikan dengan sektor pelatihan dan pengalaman kerja dalam suatu skema pengakuan kemampuan kerja yang disesuaikan dengan struktur di berbagai sektor pekerjaan.

Implikasi KKNI terhadap institusi pendidikan di lingkungan Kemeterian Pendidikan dan Kebudayaan mencakup empat hal yaitu: 1) penyetaraan capaian pembelajaran pendidikan formal dengan kualifikasi yang dinyatakan dengan berbagai jenjang pada KKNI; 2) Rekognisi Pembelajaran Lampau (RPL); 3) penyelenggaraan program dan pengaturan akses untuk pendidikan yang berbeda jenis pada berbagai strata; 4) penjaminan mutu.

Dalam upaya melakukan kualifikasi terhadap lulusan perguruan tinggi di Indonesia, pemerintah telah menerbitkan Perpres No. 08 Tahun 2012 dan UU PT No. 12 Tahun 2012 Pasal 29 ayat (1), (2), dan (3) berdampak pada kurikulum dan pengelolaannya di setiap program studi mengacu pada pencapaian kompetensi menjadi mengacu pada capaian pembelajaran (learning outcomes). Secara ringkas KKNI terdiri dari Sembilan level kualifikasi akademik SDM Indonesia. tentang Kerangka Kualifikasi Nasional Indonesia (KKNI) yang menjadi acuan dalam penyusunan capaian pembelajaran lulusan dari setiap jenjang pendidikan secara nasional untuk mencapai pembelajaran sepanjang hayat (lifelong learning).

Dalam perspektif KKNI, setiap program studi diharuskan memperjelas "profil lulusan” yang diharapkan melalui kegiatan pelacakan studi, studi kelayakan dan analisis kebutuhan di masyarakat. Profil lulusan mencerminkan kemampuan minimal yang harus dikuasai mahasiswa setelah lulus yang merujuk pada empat aspek kebutuhan (1) sikap (attitude), (2) bidang kemampuan kerja, (3) pengetahuan, dan (4) manajerial dan tanggung jawab. Keempat kemammpuan kemudian harus dijabarkan ke dalam sebuah capaian pembelajaran (learning outcome) pada setiap mata kuliah di program studi. Sehingga nantinya, semua perencanaan pembelajaran atau Rencana Pelaksanaan Semester (RPS) harus didasarkan pada capaian pembelajaran (Learning Outcome) yang sesuai dengan kebutuhan profil lulusan.

\section{Hasil dan Pembahasan}

a. Tujuan KKNI

Dengan adanya KKNI ini diharapkan akan mengubah cara melihat kompetensi seseorang, tidak lagi semata Ijazah tapi dengan melihat kepada kerangka kualifikasi yang disepakati secara nasional sebagai dasar pengakuan 
terhadap hasil pendidikan seseorang secara luas (formal, non formal, atau in formal) yang akuntanbel dan transparan.

\section{b. Mekanisme Pelaksanaan KKNI}

Pelaksanaan KKNI melalui 8 tahapan yaitu melalui penetapan Profil Kelulusan, Merumuskan Learning Outcomes (LO), Merumuskan Kompetensi Bahan Kajian, Pemetaan LO Bahan Kajian, Pengemasan Matakuliah, Penyusunan Kerangka kurikulum, Penyusuan Rencana Perkuliahan .

Kompetensi adalah akumulasi kemampuan seseorang dalam melaksanakan suatu deskripsi kerja secara terukur melalui asesmen yang terstruktur, mencakup aspek kemandirian dan tanggung jawab individu pada bidang kerjanya.

Untuk meningkatkan kualitas lulusan perguruaan tinggi, Rambu-rambu yang harus dipenuhi di tiap jenjang perlu adanya konsentrasi penuh pada beberapa hal, antara lain; (1) Learning Outcomes; (2) Jumlah SKS; (3) Waktu studi minimum; (4) Mata Kuliah Wajib untuk mencapai hasil pembelajaran dengan kompetensi umum; (5) Proses pembelajaran yang berpusat pada mahasiswa; (6) Akuntabilitas asesmen; (7) Perlunya Diploma Supplement (surat keterangan pelengkap ijazah dan transkrip) .

\section{c. Capaian pembelajaran (Learning outcomes)}

Capaian Pembelajaran (learning outcomes) merupakan internalisasi dan akumulasi ilmu pengetahuan, ketrampilan, sikap, dan kompetensi yang dicapai melalui proses pendidikan yang terstruktur dan mencakup suatu bidang ilmu/keahlian tertentu atau melalui pengalaman kerja.

Program Studi tadris Bahasa Inggris Strata Sarjana (S1) sesuai dengan KKNI Level 6. Lulusan Program Studi Pendidikan Bahasa Inggris Strata Sarjana (S1) yang baru lulus wajib menguasai: Teori, konsep, dan prinsip tentang karakteristik dan perkembangan peserta didik, serta pembimbingan dan pengembangan potensi peserta didik; menguasai teori, pendekatan. konsep dan prinsip pengembangan program pembelajaran, penyajian/ delivery, pengelolaan, dan evaluasi program pembelajaran bahasa Inggris yang mendidik; menguasai berbagai teori, konsep, dan prinsip kebahasaan, kesastraan/literasi, dan belajar bahasa serta menerapkannnya dalam pembelajaran bahasa Inggris baik untuk tujuan umum maupun khusus; menguasai kemahiran berbahasa Inggris lisan dan tulisan dalam konteks keseharian/umum, akademis, dan pekerjaan

KKNI merupakan sebuah format kurikulum yang dijadikan kerangka acuan minimal yang terukur, penjenjangan pendidikan yang dilakukan. KKNI juga disebut sebagai kerangka penjenjangan kualifikasi kompetensi yang dapat menyandingkan, menyetarakan, dan mengintegrasikan antara bidang pendidikan dan bidang pelatihan kerja serta pengalaman kerja dalam rangka pemberian 
pengakuan kompetensi kerja sesuai dengan struktur pekerjaan di berbagai sektor.

Dalam perspektif KKNI, setiap program studi diharuskan memperjelas "profil lulusan" yang diharapkan melalui kegiatan pelacakan studi, studi kelayakan dan analisis kebutuhan di masyarakat. Profil lulusan mencerminkan kemampuan minimal yang harus dikuasai mahasiswa setelah lulus yang merujuk pada empat aspek kebutuhan (1) sikap (attitude), (2) bidang kemampuan kerja, (3) pengetahuan, dan (4) manajerial dan tanggung jawab. Keempat kemammpuan kemudian harus dijabarkan ke dalam sebuah capaian pembelajaran (learning outcome) pada setiap mata kuliah di program studi. Sehingga nantinya, semua perencanaan pembelajaran atau Rencana Pelaksanaan Semester (RPS) harus didasarkan pada capaian pembelajaran (Learning Outcome) yang sesuai dengan kebutuhan profil lulusan.

Berdasarkan pada dua kebijakan tersebut, kurikulum dan KKNI Program studi tadris bahasa Inggris baik yang ada di IAIN Bengkulu dan STAIN Curup dirasa perlu merumuskan kembali Kurikulum yang betul-betul mengarah pada kebutuhan tersebut. Dari sisi KKNI, kurikulum tadris bahasa inggris harus memperjelas diri Profil Lulusan dan Capaian Kompetensi yang diharapkan, sementara dari sisi kebijakan kurikulum, konten materi ajar yang didisampaikan juga harus benar-benar merujuk pada keutuhan kebutuhan di sekolah/madrasah sebagaimana yang terdapat dalam Permendikbud No. 67 tahun 2013.

Sementara itu, secara umum di belahan dunia lain, KKNI atau yang dikenal luas sebagai National Qualification Framework (NQF) adalah isu besar yang menyeret secara bersama-sama elemen dunia pendidikan, ketenagakerjaan, dan dunia kerja .

KKNI terdiri atas sembilan jenjang yang dimulai dari tamatan pendidikan dasar (kualifikasi 1), pendidikan menengah baik SMA maupun SMK (kualifikasi 2), lulusan Diploma 1 sampai Diploma 3 (kualifikasi 3, 4, dan 5), dan lulusan pendidikan profesi (kualifikasi 6) serta S-1/Diploma 4, S-2 dan S-3 (berurutan kualifikasi $7,8,9)$.

Gambar 5

Capaian Pembelajaran/ Kompetensi Lulusan
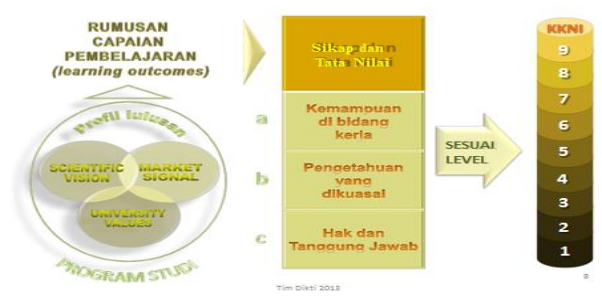

Pelaksanaan penelitian ini diinisiasi dari penelitian yang pernah peneliti lakukan sebelumnya (tahun 2015), yaitu; studi implementasi kurikulum berbasis 
KKNI pada program studi pendidikan bahasa inggris di LPTK se-kota Bengkulu, menghasilkan:

Pertama, Dengan kondisi dan persiapan yang dilakukan oleh masingmasing LPTK program studi pendidikan bahasa Inggris yang ada di kota Bengkulu menunjukkan bahwa dari lima LPTK hanya FKIP Universitas Bengkulu yang memeliki kesiapan dalam menyelenggaraan pendidikan dengan penerapan kurikulum berbasis KKNI. Sementara keempat LPTK lainnya, yaitu; FKIP UPBJJ-UT Bengkulu,FKIP Universitas Muhammadiyah Bengkulu dan Fakultas Tarbiyah dan Tadris IAIN Bengkulu belum siap menerapkan kurikulum berbasis KKNI karena terkendali pada beberapa hal tehnis internal kelembagaan.

Kedua, kendala dalam pengimplementasian kurikulum berbasis KKNI Prodi Tadris Bahasa Inggris pada masing-masing lembaga penyelenggara pendidikan (LPTK), secara gamblang dapat dikatakan bahwa kelima LPTK yang ada di Kota Bengkulu secara eksplisit belum memiliki panduan tertulis bersifat mandiri tentang mekanisme dan prosedur yang berisikan kebijakan pengembangan kurikulum. Akan tetapi secara operasional kelima LPTK ini hanya mengadopsi kebijakan yang dugariskan oleh sistem yang diatur dalam regulasi dari Direktorat Jenderal Pendidikan Tinggi (Dikti) di bawah kementerian Pendidikan dan Kebudayaan. Sedangkan LPTK di bawah payung Kementerian Agama tetap mengadopsi dari Dikti namun secar teknis pejabaran kebijakan ditafsirkan pelaksanaannya melalui Direktorat Jenderal Pendidikan Tinggi Islam (DIKTIS).

Program studi tadris Bahasa Inggris (TBI) yang diselenggarakan oleh PTKIN baik pada fakultas tarbiyah dan tadris IAIN Bengkulu, maupun jurusan tarbiyah STAIN Curup dalam perjalanannya terus berupaya menyesuaikan kualifikasi standar kompetensi lulusan, baik untuk pendidikan formal, pendidikan non formal dan keahlian. Kontekstual capaian kompetensi seperti ini dapat diwujudkan dan diselaraskan dengan adanya Kerangka Kualifikasi Nasional Indonesia (KKNI).

Persiapan dan kesiapan dalam menyusun draft kurikulum prodi tadris bahasa inggris berbasis KKNI yang ideal bagi PTKIN (IAIN Bengkulu/ STAIN Curup).

Berdasarkan hasil perolehan data melalui observasi, wawancara dan studi dokumentasi pada kedua PTKIN yang menyelenggarakan program studi bahasa Inggris, yaitu: (a) Fakultas Tarbiyah dan Tadris Institut Agama Islam Negeri (IAIN) Bengkulu; dan (b) Jurusan Tarbiyah STAIN Curup, ditemukan bahwa kondisi dan sistem penyelenggaraan program studi pendidikan bahasa Inggris pada masing-masing lembaga pendidikan tenaga kependidikan (LPTK) tersebut berlangsung baik, dinamis dan aktif. Akan tetapi masing-masing PTKIN memiliki memiliki karakter dan cirikhas tersendiri yang menunjukkan keberagaman mekanisme pola pengelolaannya karena barangkali dipengaruhi oleh faktor kultur dan demografis, dimana IAIN berada di ibu kota Provinsi, 
sedangkan STAIN Curup berlokasi di salah satu kabupaten dengan kondisi alam pergunungan dan sejuk.

Secara ringkas dapat diketahui bahwa program studi tadris bahasa Inggris dari kedua PTKIN ini memeliki peluang untuk diterapkan kurikulum berbasis KKNI karena mengingat tuntutan dan harapan pemerintah sebagaimana yang termaktub dalam peraturan presiden nomor 8 tahun 2012 dan selanjutnya secara teknis dijabarkan dalam peraturan menteri pendidikan dan kebudayaan nomor 73 tahun 2013 tentang kewajiban perguruan tinggi melalui pengelola program studi untuk segera mengimplementasikan KKNI dalam sistem pembelajaran dan pengajaran di bangku kuliah.

Disamping itu dengan kemampuan dan ketersedian sumberdaya yang ada program studi tadris bahasa Inggris yang diselenggarakan oleh IAIN Bengkulu dapat dikatakan memenuhi standar kriteria minimal meskipun disana-sini masih membutuhkan dukungan dan partisipasi semua pihak termasuk stakholder dalam mengoptimalkan segala sesuatu yang dibutuhkan untuk menunjang pemberlakukaan secara efektif kurikulum berbasis KKNI.

Akan tetapi Program studi Tadris Bahasa Inggris yang diselenggarakan oleh STAIN Bengkulu belum siap menerapkan kurikulum berbasis KKNI dengan alasan infrastruktur pendukung dan SDM yang tersedia belum memenuhi standar minimal kebutuhan.

\section{Prodi Tadris Bahasa Inggris FT'T- IAIN Bengkulu}

Visi : Menjadi pusat pengembangan pendidikan bahasa Inggris yang menghasilkan Sarjana Pendidikan yang profesional dalam bidang pendidikan dan pengajaran bahasa Inggris pada tingkat dasar sampai dengan tingkat menengah, dan menjadi pelopor perubahan dan transformasi sosial untuk memenuhi tuntutan masyarakat global berwawasan Islami pada tahun 2018.

Misi :

1. Menyelenggarakan pendidikan dan pengajaran bahasa Inggris yang berorientasi pada kemandirian yang bernuansa Islami dalam mengembangkan potensinya.

2. Menyelenggarakan penelitian dan mengembangkan ilmu pendidikan bahasa Inggris untuk tingkat dasar sampai dengan menengah,

3. Melakukan pengabdian masyarakat melalui kajian, penyuluhan, penataran, dan sejenisnya yang berkaitan dengan pendidikan dasar sampai dengan menengah yang berperspektif Islam agar mahasiswa memiliki kompetensi sebagai calon guru bahasa Inggris di sekolah atau madrasah, berwawasan luas, dan berbudi pekerti luhur.

4. Menyelenggarakan pendidikan ketauladanan dalam kehidupan, atas dasardasar nilai Islam dan budaya luhur bangsa Indonesia. 
Mengembangkan dan menanamkan kecakapan hidup berwawasan Islami untuk mempersiapkan mahasiswa menghadapi tuntutan dan tantangan dunia kerja yang modern dan global, akreditasi B. Tahun berdiri 2007, 9 dosen tetap PNS Dan 6 dosen ASN (non-PNS) Memenuhi syarat; 17 kelas; Perangkat dan fasilitas belajar-mengajar memadai dan dilengkapi TI (masih terbatas jumlahnya). Keterangan efektifitas pemberlakuan KKNI Tahun akademik 2016/2017.

Prodi Tadris Bahasa Inggris, Jurusan Tarbiyah STAIN Curup

Visi : Mewujudkan Prodi Tadris Bahasa Inggris yang memiliki karakteristik kritis, idealis, kreatif, inovastif dan adaptif dengan melihat perkembangan pada ilmu kebahasaan dan perkembangan dunia pendidikan, sehingga mampu prodi Tadris Bahasa Inggris STAIN Curup menjadi program studi yang mampu mempersiapkan sarjana yang memiliki kemampuan akademik yang profesional serta memiliki keluhuran akhlak sebagai Sarjana Pendidikan Modern dimasa datang.

Misi:

1. Menyelenggarakan Pendidikan dan pengajaran yang profesional sehingga menciptakan lulusan yang memiliki potensi yang sesuai dengan kurikulum berbasis kompetensi (kurikulum 2004).

2. Menyelenggarakan pendidikan dan pengajaran dengan didasari oleh nilai-nilai keislaman sehingga dapat mempersiapkan sarjana yang memiliki keluhuran akhlak, kecakapan dan keluasan ilmu serta kematangan dibidang ilmu keahlianya akan membentuk sarjana modern yang profesiaonal.

3. Melakukan pengabdian pasa masyarakat dengan mampu memecahkan permasalahan-permasalahan yang terjadi di lingkungan nya secara akademis dan agamis serta dapat mengembangkan ilmu bahasa Inggris Islam profesional.

4. Dalam menyelenggarakan pendidikan dan pengajaran selalu menjaga nilainilai religius dan profesional-akademik sehingga membentuk sarjana yang mampu menggabungkan dua sinergis yang akan mendasari sarjana STAIN Curup menjadi sarjana yang profesional

5. Menghasilkan sarjana yang mampu secara profesional dan dapat menggunakan ilmu bahasa Inggris Islam terhadap perkembangan era globalisasi dimasa akan datang.

Berdiri 2003, 10 dosen tetap dan 17 dosen tidak tetap, Memenuhi syarat; 17 kelas; Perangkat dan fasilitas belajar-mengajar memadai dan dilengkapi TI (masih terbatas jumlahnya), Tahun akademik 2017/2018.

1. Materi inti sebagai konten kurikulum prodi tadris bahasa inggris berbasis KKNI.

Merujuk pada porsi atau muatan dari setiap materi dalam penerapan kurikulum selama ini diterapkan pada prodi tadris bahasa inggris dari kedua 
PTKIN mengacu pada Surat Keputusan MENDIKNAS RI NO. 045/U/2002. tentang kurikulum inti pendidikan tinggi antara lain; elemen kompetensi yang memuat topik ; (1) Landasan kepribadian; (2) Penguasaan ilmu dan ketrampilan; (3) Kemampuan berkarya; (4) Sikap dan perilaku dalam berkarya; dan (5) Pemahaman kaidah berkehidupan bermasyarakat. Dan kompetensi Utama ditetapkan oleh kalangan Perguruan Tinggi, masyarakat profesi dan pengguna lulusan. kompetensi Pendukung dan Kompetensi lainnya ditetapkan oleh Institusi penyelenggara program studi dimana setiap komponen dan elemen dari kompotensi ini memiliki kapasitas sesuai dengan porsinya masing, sebagaimana yang tertera dalam tabel berikut;

Muatan kurikulum prodi tadris bahasa Inggris dari kedua PTKIN secara umum memuat lima kompetensi yang dibutuhkan untuk berhasil dalam menjalankan profesi tersebut, yaitu;

\section{a. Profesi Utama}

Kompetensi Komponen, berupa pengetahuan, sikap, dan keterampilan, antara lain;

a. Memiliki Kecerdasan intelektual , Kecerdasan emosional dan kecersdasan spiritual yang memadai. Mahasiswa diharapkan memiliki kemampuan (kompetensi) akademik dan professional dalam bidang Ilmu Agama Islam beserta penerapan nya di dalam masyarakat. Mahasiswa dituntut untuk menguasai wawasan pendidikan yang komprehensif dan menguasai substansi ilmu-ilmu Bahasa Inggris dan metodologi pembelajaran nya;

b. Memiliki pengetahuan tentang Islam secara komprehensif. wawasan ilmu kependidikan dan kebahasaan. Menguasai substansi ilmu-ilmu Bahasa Inggris dan metodologi pengajarannya;

c. Memiliki integritas kepribadian, baik agama, moral, etika, profesionalisme dan dapat berpenampilan sesuai dengan profesinya.

d. Memiliki keterampilan berbahasa (Indonesia, Inggris dan Arab).

e. Memiliki keterampilan dalam berfikir dan mengelola informasi.

f. Memilki keterampilan dan tanggung jawab profesi.

2. Penyatuan persepsi pengelola prodi dalam pemenuhan kualifikasi integrasi muatan (content) kurikulum berbasis KKNI program studi tadris bahasa Inggris pada Perguruan Tinggi Keagamaan Islam Negeri (PTKIN).

Penyatuan persepsi yang dilakukan melalui FGD dan pembahasan secara intensif yang dilakukan oleh kedua pelaksana Prodi tadris bahasa Inggris dan tim baik dari IAIN Bengkulu dan STAIN Curup menghasilkan kesepakatan tentang draft isian kurikulum TBI berbasis KKNI, (terlampir)

Upaya pembaharuan kurikulum merupakan tugas rutin setiap institusi pendidikan,dalam hal ini khususnya Fakultas kependidikan/Tarbiyah sebagai 
wadah LPTK dengan prodi/Jurusan pendidikan bahasa Inggris, proses ini juga dilakukan secara regular, berkala, dan konsisten. Oleh sebab itu institusi harus mempunyai tim yang bertanggung jawab dalam pengembagan kurikulum.

Menurut pandangan Menteri pendidikan dan kebudayaan RI dalam salah satu artikel, bahwa pada dasarnya kurikulum merupakan perencanaan pembelajaran yang dirancang berdasarkan tujuan yang telah ditetapkan dalam visi-misi lembaga pendidikan. Proses perancangannya diawali dengan menentukan kompetensi lulusan (standar kompetensi lulusan). Hasilnya, kurikulum jenjang satuan pendidikan. Dalam teori manajemen, sebagai sistem perencanaan pembelajaran yang baik, kurikulum harus mencakup empat hal. Pertama, hasil akhir pendidikan yang harus dicapai peserta didik (keluaran), dan dirumuskan sebagai kompetensi lulusan. Kedua, kandungan materi yang harus diajarkan kepada, dan dipelajari oleh peserta didik (masukan/standar isi), dalam usaha membentuk kompetensi lulusan yang diinginkan. Ketiga, pelaksanaan pembelajaran (proses, termasuk metodologi pembelajaran sebagai bagian dari standar proses), supaya ketiga kompete nsi yang diinginkan terbentuk pada diri peserta didik. Keempat, penilaian kesesuaian proses dan ketercapaian tujuan pembelajaran sedini mungkin untuk memastikan bahwa masukan, proses, dan keluaran tersebut sesuai dengan rencana.

Penerapan Kurikulum berbasis KKNI di Perguruan tinggi menjadi topik hangat untuk diperbincangkan di kalangan pengelola pendidikan tinggi sejalan dengan instruksi pemerintah melalui permendikbud No.73 tahun 2013 sebagai penjelasan dari peraturan presiden nomor 8 tahun 2010 tentang implementasi KKNI, memunculkan berbagai argumentasi dan penafsiran, antara lain bahwa KKNI dipahami sebatas kurikulum, akibatnya mayoritas perguruan tinggi di Indonesia saat ini demam kurikulum KKNI. Padahal KKNI tidak hanya membidangi pendidikan tinggi, melainkan berbagai sektor,seperti tenaga kerja, birokrasi pemerintah, pelatihan, industri, dunia usaha, dll.

Fenomena ini secara langsung juga berimbas pada eksistensi dan penerapan Kurikulum di Lembaga Pendidikan Tinggi Keguruan (LPTK). Sebab, LPTK sebagai lembaga pencetak bibit unggul bagi generasi pendidika diharapkan sedikit banyak adanya upaya dan strategi pembaharuan kurikulum yang sesuai kebutuhan dan tuntutan dari publik. Melalui LPTK tentu akan menghasilkan calon tenaga pendidik yang beorientasi terhadap ilmu dan mata kuliah, dan dapat menunjang kemampuan dalam mengajarkan masingmasing disiplin ilmu. Mata kuliah yang diajarkan pun mengantarkan lulusannya untuk menguasai kedua kemampuan tersebut dengan capaian pembelajaran/ Learning outcomes Program Studi Pendidikan Bahasa Inggris Strata Sarjana (S1) sesuai dengan KKNI Level 6.

Lulusan Program Studi Pendidikan Bahasa Inggris Strata Sarjana (S1) yang baru lulus wajib menguasai: Teori, konsep, dan prinsip tentang 
karakteristik dan perkembangan peserta didik, serta pembimbingan dan pengembangan potensi peserta didik; menguasai teori, pendekatan. konsep dan prinsip pengembangan program pembelajaran, penyajian/ delivery, pengelolaan, dan evaluasi program pembelajaran bahasa Inggris yang mendidik; menguasai berbagai teori, konsep, dan prinsip kebahasaan, kesastraan/literasi, dan belajar bahasa serta menerapkannnya dalam pembelajaran bahasa Inggris baik untuk tujuan umum maupun khusus; menguasai kemahiran berbahasa Inggris lisan dan tulisan dalam konteks keseharian/umum, akademis, dan pekerjaan setara tingkat pre-advanced dengan kemampuan;

1) Memecahkan masalah belajar dan pembelajaran bahasa Inggris sebagai bahasa asing dalam lingkup sederhana dengan menerapkan teori, pendekatan, konsep, atau prinsip yang berkaitan dengan desain dan model pembelajaran bahasa, kebahasaan, kesastraan, belajar, dan pembelajaran bahasa sebagai alat identifikasi dan analisis;

2) Mengahasilkan simpulan terhadap masalah belajar dan pembelajaran bahasa Inggris sebagai bahasa asing dengan tepat berdasarkan hasil identifikasi dan analisis;

3) Menyajikan beberapa pilihan pemecahan masalah di bidang belajar dan pembelajaran bahasa Inggris sebagai asing berdasarkan identifikasi dan analisis sederhana;

4) Merencanakan, menerapkan, mengelola, mengevaluasi, serta melakukan perbaikan belajar dan pembelajaran bahasa Inggris sebagai bahasa asing baik untuk tujuan umum maupun khusus berdasarkan identifikasi dan analisis karakteristik dan kebutuhan peserta didik serta pemangku kepentingan;

5) Mendesiminasikan hasil kajian terhadap masalah belajar dan pembelajaran bahasa Inggris sebagai bahasa asing dalam bentuk laporan ilmiah atau kertas kerja; dan

6) Bertanggungjawab pada pekerjaan sebagai guru muda secara mandiri dan dapat diberi tanggung jawab atas pencapaian hasil kerja lembaga/insititusi dengan dilandasi oleh sikap, perilaku yang diwarnai oleh nilai-nilai kearifan lokal dan ahlak mulia serta memiliki motivasi untuk berbuat bagi kemaslahatan peserta didik dan masyarakat pada umumnya

Prospek kurikulum berbasis KKNI ini secara tidak langsung sebenarnya memiliki hubungan resiprokal dengan prodi Pendidikan bahasa Inggris yang berperan sebagai Lembaga Pendidikan Tenaga Kependidikan (LPTK) dengan mengintegrasikan pola Pendidikan Profesi Guru (PPG), dimana muatan silabus dan Rancangan pembelajarannya menitiberatkan pada penguasaan empat keterampilan belajar bahasa Inggris, yaitu speaking (berbicara), Writing (menulis), reading (membaca) dan Listening (mendengar). Akan tetapi secara keseluruhan proses belajar-mengajar yang dilangsungkan nanti tetap mengacu pada kerangka nasional sebagaimana yang dituangkan dalam peraturan presiden 
RI nomor 8 tahun 2012 tentang Kerangka Kualifikasi Nasional Indonesia dan diterjemahkan dalam peraturan menteri pendidikan dan kebudayaan RI nomor 73 tahun 2013 tentang penerapan KKNI di LPTK.

Secara operasional melalui penerapan kurikulum berbasis KKNI dalam proses kegiatan akademik pada prodi pendidikan bahasa Inggris yang diselenggarakan oleh kedua PTKIN, paling tidak diharapkan tewujudnya sasaran sebagaimana yang diharapkan berikut:

a. Kurikulum Berbasis Learning Outcomes (KBO) Program Studi Pendidikan Bahasa Inggris Berbasis KKNI

Kerangka Kualifikasi Nasional Indonesia disingkat KKNI ialah acuan penjenjangan kualifikasi kompetensi untuk pengakuan kerja. KKNI telah dirumuskan oleh Mendikbud pada 2010 sebagai acuan pengembangan kurikulum. KKNI kemudian diundangkan melalui Peraturan Presiden Nomor 8 Tahun 2012 tentang Kerangka Kualifikasi Nasional Indonesia.

Kehadiran KKNI sebenarnya merupakan acuan umum bagaimana kualifikasi seseorang mendapat pengakuan di dunia kerja. Mendikbud menjelaskan: kebutuhan Indonesia untuk segera memiliki KKNI sudah sangat mendesak mengingat tantangan dan persaingan global pasar tenaga kerja nasional maupun internasional semakin terbuka. Pergerakan tenaga kerja dari dan ke Indonesia tidak lagi dapat dibendung dengan peraturan atau regulasi yang bersifat protektif

Agar dalam jangka pendek dan jangka panjang Indonesia mampu bertahan tetapi tetap bergerak maju di arena ekonomi global, maka pengakuan timbal balik dan setara dengan negara asing menjadi butir-butir yang kritis dalam pengembangan suatu kerangka kualifikasi tenaga kerja nasional.

Ada tiga strategi pengembangan KKNI; Pertama, KKNI menganut strategi kesetaraan kualifikasi seseorang yang diperoleh dari dunia pendidikan formal, nonformal, informal dan pengalaman bekerja; Kedua, KKNI mengakui kualifikasi pemegang ijazah yang akan bekerja maupun melanjutkan pendidikan di luar negeri, pertukaran pakar dan mahasiswa lintas negara atau pemegang ijazah dar luar negeri yang bekerja di Indonesia; Ketiga, KKNI mengakui kesetaraan kualifikasi capaian pembelajaran berbagai bidang keilmuan pada tingkat pendidikan tinggi, baik yang berada pada jalur pendidikan akademik, vokasi, profesi, serta melalui pengembangan karir yang terjadi di strata kerja, industri atau asosiasi profesi.

Sementara itu, KKNI terdiri dari 9 jenjang kualifikasi. Deskripsi jenjang kualifikasi KKNI menurut Perpres No. 8 Tahun 2012 diuraikan dalam bagan berikut ; 1) Jenjang 1 sampai 3 dikelompokkan dalam jabatan operator diduduki lulusan SD, SMP dan SMA; 2) Jenjang 4 sampai 6 dikelompokkan dalam jabatan teknisi atau analis, diduduki oleh lulusan D1, D2, D3, D4 dan Sarjana. 3) Jenjang 7 dikelompokkan dalam jabatan ahli, diduduki oleh lulusan pendidikan profesi; 4) Jenjang 8 dikelompokkan dalam jabatan ahli diduduki oleh lulusan magister atau spesialis; 5) Jenjang 9 dikelompokkan dalam jabatan ahli diduduki oleh lulusan doktor atau spesialis. Selanjutnya secara konseptual, 
setiap jenjang kualifikasi dalam KKNI disusun oleh empat parameter, yaitu: (1) keterampilan kerja, (2) cakupan keilmuan (pengetahuan), (3) metode dan tingkat kemampuan mengaplikasikan keilmuan, dan (4) kemampuan manajerial.

Internalisasi dan akumulasi keempat parameter yang harus dicapai melalui proses pendidikan yang terstruktur atau melalui pengalaman kerja disebut dengan learning outcomes atau capaian pembelajaran.

Capaian pembelajaran/ Learning outcomes Program Studi Pendidikan Bahasa Inggris Strata Sarjana (S1) sesuai dengan KKNI Level 6

Lulusan Program Studi Pendidikan Bahasa Inggris Strata Sarjana (S1) yang baru lulus wajib menguasai: Teori, konsep, dan prinsip tentang karakteristik dan perkembangan peserta didik, serta pembimbingan dan pengembangan potensi peserta didik; menguasai teori, pendekatan.

Konsep dan prinsip pengembangan program pembelajaran, penyajian/ delivery, pengelolaan, dan evaluasi program pembelajaran bahasa Inggris yang mendidik; menguasai berbagai teori, konsep, dan prinsip kebahasaan, kesastraan/literasi, dan belajar bahasa serta menerapkannnya dalam pembelajaran bahasa Inggris baik untuk tujuan umum maupun khusus; menguasai kemahiran berbahasa Inggris lisan dan tulisan dalam konteks keseharian/umum, akademis, dan pekerjaan setara tingkat pre-advanced dengan kemampuan:

1) Memecahkan masalah belajar dan pembelajaran bahasa Inggris sebagai bahasa asing dalam lingkup sederhana dengan menerapkan teori, pendekatan, konsep, atau prinsip yang berkaitan dengan desain dan model pembelajaran bahasa, kebahasaan, kesastraan, belajar, dan pembelajaran bahasa sebagai alat dentifikasi dan analisis;

2) Menghasilkan simpulan terhadap masalah belajar dan pembelajaran bahasa Inggris sebagai bahasa asing dengan tepat berdasarkan hasil identifikasi dan analisis;

3) Menyajikan beberapa plihan pemecahan masalah di bidang belajar dan pembelajaran bahasa Inggris sebagai asing berdasarkan identifikasi dan analisis sederhana;

4) Merencanakan, menerapkan, mengelola, mengevaluasi, serta melakukan perbaikan belajar dan pembelajaran bahasa Inggris sebagai bahasa asing baik untuk tujuan umum maupun khusus berdasarkan identifikasi dan analisis karakteristik dan kebutuhan peserta didik serta pemangku kepentingan;

5) Mendesiminasikan hasil kajian terhadap masalah belajar dan pembelajaran bahasa Inggris sebagai bahasa asing dalam bentuk laporan ilmiah atau kertas kerja; dan

6) bertanggungjawab pada pekerjaan sebagai guru muda secara mandiri dan dapat diberi tanggung jawab atas pencapaian hasil kerja lembaga/insititusi dengan dilandasi oleh sikap , perilaku yang diwarnai oleh nilai-nilai kearifan lokal dan ahlak mulia serta memiliki motivasi untuk berbuat bagi kemaslahatan peserta didik dan masyarakat pada umumnya; 
7) Ada 5 ketrampilan yang harus dipenuhi oleh seorang lulusan perguruan tinggi agar dapat bersaing, yaitu kemampuan berkomunikasi secara verbal, kolaborasi, profesional di bidangnya, mampu menulis dengan baik, serta kemampuan untuk memecahkan masalah.

8) Ada beberapa hal yang digarisbawahi tentang bagaimana model pembelajaran yang sesuai dengan ciri abad ke-21, yaitu pembelajaran yang diarahkan untuk mendorong peserta didik mencari tahu dari berbagai sumber observasi, dan bukan diberitahu, pembelajaran yang diarahkan untuk mampu merumuskan masalah, bukan hanya menjawab masalah, pembelajaran yang diarahkan untuk melatih berfikir analitis dan bukan berfikir mekanistis, serta pembelajaran yang menekankan pentingnya kerjasama dan kolaborasi dalam menyelesaikan masalah.

\section{Penutup}

Pertama; Kedua PTKIN yang menyelenggarakan program studi bahasa Inggris, menunjukan kesiapan yang signifikan dalam penerapan kurikulum berbasis KKNI sesuai dengan kondisi dan sistem penyelenggaraan kegiatan akademik berlangsung baik, dinamis dan aktif. Akan tetapi meski di bawah satu kementerian, masing-masing PTKIN memiliki memiliki karakter dan cirikhas tersendiri yang menunjukkan keberagaman mekanisme pola pengelolaannya karena dipengaruhi oleh faktor kultur dan demografis, dimana IAIN berada di ibu kota Provinsi, sedangkan STAIN Curup berlokasi di salah satu kabupaten dengan kondisi alam pergunungan dan sejuk;

Kedua: Materi inti sebagai konten kurikulum prodi tadris bahasa inggris berbasis KKNI pada kedua PTKIN mengacu pada elemen kompetensi yang memuat topik ; (1) Landasan kepribadian; (2) Penguasaan ilmu dan ketrampilan; (3) Kemampuan berkarya; (4) Sikap dan perilaku dalam berkarya; dan (5) Pemahaman kaidah berkehidupan bermasyarakat.

Ketiga: Kualitas Kurikulum merupakan faktor penting untuk mencapai keberhasilan mutu pelaksanaan pendidikan dan pencapaian mutu kompetensi lulusan, yang terdiri atas unsur-unsur : Mata kuliah, Kompetensi berdasarkan kebutuhan pelanggan, Bobot (sistem kredit semester) setiap mata kuliah, deskripsi mata kuliah (sinopsis), yang dilengkapi dengan kepustakaan.

Pengelompokkan mata kuliah berdasarkan jenis dan tujuannya, dan penyebaran mata kuliah sesuai porsi yang menunjukkan aspek sikap, pengetahuan, ketrampilan serta penerapan dalam dunia kerja.

\section{Daftar Pustaka}

Akbarjono, Ali. 2015. studi implementasi kurikulum berbasis KKNI pada program studi pendidikan bahasa inggris di LPTK se-kota Bengkulu. LPPM IAIN Bengkulu. 
Anik Ghufron (Guru Besar Fakultas Ilmu Pendidikan Universitas Nasional Yogyakarta. Artikel. Pemutakhiran Kurikulum Perguruan Tinggi.

Asep Herry Hernawan. Dkk. 2011. Kurikulum dan pembelajaran. Tim Pengembang MKDP. Jakarta: Rajawali Pers.

Buku Panduan Kurikulum Pendidikan Tinggi. 2014 Direktorat Pembelajaran \& Kemahasiswaan Irektorat Jenderal Pendidikan Tinggi Kementerian Pendidikan Dan Kebudayaan.

Daniel Tanner dan Laurel Tanner .http://www.artikelsiana.com/2015/02/pengertian-kurikulum-definisi-paraahli-kurikulum.html

Direktorat Jenderal Pendidikan Tinggi. 2013. Pedoman Pengembangan Kurikulum LPTK

Dodi Novianto. Pengembangan Kurikulum Pendidikan Pada Program Studi Pendidikan Agama Islam Fakultas Tarbiyah STAIN/IAIN/UIN (LPTK Disampaikan dalam Seminar Mata Kuliah Pengembangan Kurikulum Pendidikan Islam - Program Magister Manajemen Pendidikan Islam - UIN MALIKI Malang tanggal 1 Desember 2010.didownload dari: http:/ / dedinoviyanto.wordpress.com/my-papers/

Frey, Kevin B. 2011. Developing a model Curriculum in surgical Technology. AST Education and Accreditation Manager. paper didownload dari

http://www.ast.org/uploadedFiles/Main_Site/Content/Educators/Developin g\%20a\%20Model $\% 20$ Curriculum.pdf

Haidar Putra Daulay. 2007. Pendidikan Islam dalam Sistem Pendidikan Nasional Indonesia, (Jakarta: Kencana,hal. 94

Higher Education in the Twenty-first Century: Vision and Action. World Conference on Higher Education. UNESCO, Paris, 5-9 October1998.

Indonesian Qualification Framework. 2010. Buku Pedoman Kerangka Kualifikasi Nasional. Edisi.1. Direktorat Jenderal Pendidikan Tinggi. Kementerian Pendidikan Nasional RI

Indonesian Qualification Framework. 2010. Buku Pedoman Kerangka Kualifikasi Nasional. Edisi.1. Direktorat Jenderal Pendidikan Tinggi. Kementerian Pendidikan Nasional RI.

Inglis, AlexanderJames. 2010. Principle of Secondary Education. Assistant Professor Of Education Harvard University Houghton Mifflin Company Boston New York Chicago didownload dari ks at: http://scholarcommons.usf.edu/etd

Kampus Wajib Terapkan

KKNI http://pendis.kemenag.go.id/index.php?a=detilberita\&id. diunduh Kamis, 04 Oktober 2015.

Kementerian Pendidikan dan Kebudayaan Universitas Terbuka. Katalog 2015 UT 
Kunaefi, Tresna Dermawan.2008. Buku Panduan Pengembangan Kurikulum Berbasis Kompetensi Pendidikan Tinggi. Sebuah alternatif Penyusunan kurikulum. Dikti: Jakarta.

Menteri Pendidikan dan Kebudayaan.2010. Acuan Pengembangan Kurikulum

Menteri Pendidikan dan Kebudayaan.2010. Acuan Pengembangan Kurikulum

Moeleong Lexy. Metodologi Penelitian kualitatif. Remaja Rosdakarya, Bandung

Moh.Yamin.2012. Panduan Manajemen Mutu Kurikulum Pendidikan: Panduan Lengkap tat kelola kurikulum efektif. Yogyakarta: Diva Press.

Mohammad Nuh. Menteri Pendidikan dan Kebudayaan RI Artikel. Kurikulum 2013 Sudah Dimuat di Harian Kompas, Kamis, 7 Maret 2013 dan didownload dari: http://kemdikbud.go.id/kemdikbud/artikel-mendikbudkurikulum2013

Panduan Penyusunan Capaian Pembelajaran Lulusan Program Studi. 2014. Kementerian Pendidikan Dan Kebudayaan Direktorat Pembelajaran Dan Kemahasiswaan Direktorat Jenderal Pendidikan Tinggi

Pedoman Pengembangan Kurikulum LPTK

Peraturan menteri pendidikan dan Kebudayaan nomor 49 tahun 2014

Peraturan Pemerintah RI nomor 19 tahun 2005 tentang standar nasional pendidikan (SNP)

Peraturan Presiden RI nomor 8 tahun 2012 tentang Kerangka Kualifikasi Nasional Indonesia

Peraturan Presiden RI nomor 8 tahun 2012 tentang Kerangka Kualifikasi Nasional Indonesia

Pernyataan Menteri Pendidikan dan Kebudayaan RI. Prof.DR.Moh.Nuh pada sebuah seminar di Universitas Nasional Surabaya . didownload dari: http://kemdikbud.go.id/kemdikbud/berita/1462)

Pratt, David. (1980).Curriculum Design and Development. New York: Harcourt

Pratt, David. (1980).Curriculum Design and Development. New York: Harcourt.

Sukmadinata, Nana Syaodih. 2012. Pengembangaan Kurikulum, Teori dan Praktek. Bandung : Remaja Rosdakarya

Suryosubroto, B. 2005. Tatalaksana Kurikulum. Jakarta: Rineka Cipta.

Sutrisno dan Suyadi. 2015. Desain Kurikulum Pendidikan Tinggi Berbasis KKNI.edisi pracetak (UIN SUKA Jogyakarta) hal.9

Sutrisno dan Suyadi. 2015.edisi pracetak. Desain Kurikulum Pendidikan Tinggi Berbasis KKNI. Yogyakarta: UIN Press.

Undang-undang Republik Indonesia. Nomor 12 tahun 2012 tentang pendidikan tinggi

Undang-undang RI nomor 14 tahun 2005.tentang Guru dan Dosen..

Undang-undang RI Nomor 20 tahun 2003 tentang sistem Pendidikan Nasional. 